\title{
MANAJEMEN PERSEDIAAN TEPUNG TERIGU DENGAN METODE ECONOMIC ORDER QUANTITY (EOQ) PADA PERUSAHAAN ROTI NIKKI ECHO PAYAKUMBUH
}

\author{
Desi Rahma Yani ${ }^{1}$, Mega Amelia Putri ${ }^{2}$, John Nefri ${ }^{2}$ \\ ${ }^{1}$ Mahasiswa Politeknik Pertanian Negeri Payakumbuh \\ ${ }^{2}$ Dosen Pembimbing Mahasiswa Politeknik Pertanian Negeri Payakumbuh \\ Email: megaamelia@yahoo.com
}

\begin{abstract}
Inventory management has an important role in a company because inventory management can decrease production cost. Economic order quantity using to minimize the production cost. Inventory management of flour in bread company Nikki Echo not been seen clearly prove by so many booking amount. It can giving addition of cost. The purpose of this research is (1) Analyzing optimal flour stock by using EOQ method in bread company Nikki Echo, (2) Analyzing reorder point raw material inventory by using EOQ method in bread company Nikki Echo, (3) Analyzing total raw material inventory cost by using EOQ method in bread company Nikki Echo. This research be held from February 20 until April 192018 in bread company Nikki Echo, Tanjung Pauh, Payakumbuh city, West Sumatera province. Flour stock by using EOQ method as much $17.394 \mathrm{~kg}$ it means the amount greater than company policy. That amount increase 79,6\% from the amount set by company. Frequency of booking less than company policy that is 7 times booking. Amount of reorder by using EOQ method is $10.251 \mathrm{~kg}$ with the inventory lead time for 3 days. Total inventory cost by using EOQ method as many Rp 11.445.513. This value small than total inventory cost issued by company policy. Decreasing cost amount $98 \%$ from company policy. That cause by ordering amount reduced 33 times or same with $82,5 \%$ from the amount before.
\end{abstract}

Keywords: economic order quantitiy (EOQ), reorder point, flour.

\section{PENDAHULUAN}

Sebuah perusahan memiliki tujuan utama yaitu memperoleh laba. Dalam proses pencapaian tujuan tersebut akan dipengaruhi oleh berbagai faktor,salah satu faktor itu ialah kelancaran produksi. Kelancaran produksi dipengaruhi oleh manajemen-manajemen yang diterapkan dalam perusahaan dintaranya manajemen sumberdaya manusia, manajemen produksi, manajemen penyimpanan, dan manajemen pemasaran. Pencapaian tujuan perusahaan akan menghadapi kendala tertentu sehingga perusahaan harus memiliki manajemen yang baik. Manajemen yang baik memiliki fungsi yang sangat penting dalam perusahaan guna melakukan pemilihan keputusan serta sebagai kontrol dalam kegiatan perusahaan. Manajemen persediaan memiliki peranan yang penting dalam perusahaan karena manajemen persediaan dapat mengurangi biaya produksi berupa biaya pemesanan bahan baku dan biaya penyimpanan, sehingga meningkatkan laba yang diperoleh perusahaan.Persediaan yang optimal membantu perusahaan menentukan seberapa besar persediaan bahan baku yang sesuai, sehingga tidak menimbulkan pemborosan biaya karena mampu menyeimbangkan kebutuhan bahan baku dengan penggunannya.

Nikki Echo merupakan sebuah perusahaan industri roti bertempat di tanjung pauh, Payakumbuh. Pembuatan jenis-jenis roti yang dihasilkan Nikki Echo bersumber dari bahan baku utama berupa tepung terigu dengan protein tinggi. Perusahaan roti Nikki Echo suah memiliki P-IRT dengan no.2.06.1376.01.103, dan sudah memiliki label halal dari Majelis Ulama Indonesia (MUI). Salah satu produk roti yang mudah ditemui di kalangan masyarakat adalah roti tawar dengan aneka ukuran dan varian rasa. Tepung terigu merupakan salah satu jenis tepung yang berasal dari gandum. Tepung terigu yang digunakan di perusahaan roti Nikki Echo adalah tepung terigu dengan protein tinggi. Komposisi tepung adalah gandum, premix, vitamin, dan mineral. Kandungan gluten pada terigu yang digunakan 
sebesar $12-14 \%$. Kusuma (2009) menyatakan masalah utama persediaan bahan baku adalah penetapan pesanan ekonomis.

Model Economic Order Quantity (EOQ) merupakan model dengan tingkat pemesanan yang meminimasi biaya persediaan keseluruhan. Model ini digunakan untuk persediaan bahan baku dengan laju permintaan tetap. Apabila permintaan tidak tetap, model EOQ tidak dapat diterapkan dengan sempurna. Kondisi ini terjadi bila permintaan mengikuti pola musiman, kontrak, atau kerusakan mesin (Kusuma,2009).

Manajemen persediaan bahan baku tepung terigu di roti Nikki Echo belum terlihat dengan jelas, hal ini dibuktikan dengan frekuensi pemesanan yag terlalu besar dalam satu tahun yaitu sebanyak 40 kali pemesanan. Pemesanan yang terlalu sering akan menimbulkan penambahan biaya pada kegiatan produksi yaitu berupa biaya pemesanan. Untuk meminimalisir biaya pemesanan yang dikeluarkan perusahaan, maka perlu adanya penentuan jumlah pesanan ekonomis. Karena dalam pembuatan roti, tepung terigu memiliki persentase biaya bahan yang tinggi yaitu 48,5\%. Dengan demikian tujuan untuk memperoleh laba akan semakin mudah dicapai.

Perumusan masalah dalam penelitian ini adalah (1) Berapa besar persediaan tepung terigu yang optimal dengan menggunakan Metode EOQ pada perusahaan Roti Nikki Echo?, (2) Berapa besar Reorder point persediaan bahan baku dengan menggunakan metode EOQ pada perusahaan Roti Nikki Echo ?, (3) Berapa besar total biaya dengan menggunakan metode EOQ pada perusahaan Roti Nikki Echo?. Tujuan penelitian ini adalah untuk (1) Menganalisis persediaan tepung terigu yang optimal dengan menggunakan metode EOQ pada perusahaan roti Nikki Echo (2) Menganalisis besarnya reorder point persediaan bahan baku dengan menggunakan metode EOQ pada perusahaan roti Nikki Echo (3) Menganalisis total biaya persediaan bahan baku dengan menggunakan metode EOQ pada perusahaan roti Nikki Echo.

\section{METODE PENELITIAN}

Penelitian ini dilakukan di perusahaan roti Nikki Echo yang terletak diJl. Marah Adin, Tanjung Pauh, Kota Payakumbuh pada 20 februari sampai 19 april 2018 saat melakukan kegiatan Pengalaman Kerja Praktek Mahasiswa (PKPM). Perusahaan ini bergerak dibidang usaha produksi roti dengan bahan baku utama tepung terigu. Penelitian diawali dengan diskusi dengan pihak perusahaan mengenai judul tugas akhir dan data-data yang akan diperlukan selama penyusunan tugas akhir. Dilakukan pengecekan bahan baku di gudang selama kegiatan magang seminggu sekali ketika bahan baku sampai disuruh oleh pimpinan untuk ikut serta dalam pengecekan bahan baku yang masuk ke gudang. Data penelitian juga dilengkapi dengan wawancara langsung kepada divisi gudang, administrasi, dan pimpinan perusahaan. Setelah data lengkap, dilakukan pengolahan data secara deskriptif kuantitatif. Pengumpulan data dilakukan dengan mengamati secara langsung kegiatan-kegiatan yang berhubungan dengan penelitian di perusahaan roti Nikki Echo. pengumpulan data juga dilakukan dengan studi kepustakaan melalui jurnal-jurnal penelitian dan buku-buku yang berhubungan dengan penelitian yang sedang dilakukan.

\section{Analisis Data}

Metode yang digunakan dalam penelitian ini merupakan metode deskriptif-kuantitatif. Yaitu mengolah dengan rumus-rumus statistik yang sudah disediakan, baik secara manual maupun dengan menggunakan jasa komputer. Alat pengolahan data yang digunakan untuk menjawab permasalahan penelitian ini adalah sebagai berikut:

\section{Economic Order Quantity (EOQ)}

Untuk mendapatkan jumlah pembelian bahan baku yang optimal setiap kali pemesanan dengan biaya minimal dapat ditentukan dengan Economic Order Quantity(EOQ) dan Reorder Point (ROP). Perhitungan EOQ dapat diformulasikan sebagai berikut;

$$
\mathrm{EOQ}=\sqrt{\frac{2 R S}{P I}}
$$

Keterangan :

$\mathrm{R} \quad=$ kuantitas yang diperlukan selama periode tertentu

$\mathrm{S} \quad=$ Biaya pemesanan setiap kali pesan disebut denganprocurement cost atau ordering cost atau setup cost. 
$\mathrm{P} \quad=$ Harga bahan per unit

I = Biaya penyimpanan bahan baku digudang dinyatakandalam persentase dari nilai persediaan rata-rata

dalam satuanmata uang yang disebut carrying cost atau storage cost atauholding cost.

PxI = Besarnya biaya penyimpanan bahan baku per unit.

2. Frekuensi Pembelian

Frekuensi pembelian dapat diformulasikan sebagai berikut:

$$
\mathrm{I}=\frac{D}{E O Q}
$$

Keterangan:

I = frekuensi pemesanan dalam satu tahun

$\mathrm{D}=$ jumlah kebutuhan bahan selama setahun

$\mathrm{EOQ}=$ jumlah pembelian bahan sekali pesan

3. Persedian Pengaman (safety stock)

Persediaan pengaman yaitu jumlahpersediaan bahan minimum yang harus dimiliki oleh perusahaanuntuk menjaga kemungkinan keterlambatan datangnya bahanbaku, sehingga tidak terjadi stagnasi. Besarnya safety stockditentukan denganrumus:

Safety stock $=($ pemakaian maksimum-pemakaian rata-rata $) \times$ Lead time

4. Titik pemesanan kembali (reorder point)

Dalam penentuan reorder point harus mempehatikan hal sepertipenggunaan material selama jangka waktu sebelum pesanandating dan jumlah safety stock. Karena berkaitan dengan berapa sisapersediaan yang terdapat digudang, baru dilakukan pemesanankembali. Formulasi reorder point adalah sebagai berikut:

Keterangan ;

$$
\text { Reorder Point }=(\mathrm{LD} \times \mathrm{AU})+\mathrm{SS}
$$

$\mathrm{LD}=$ Lead time atau waktu tunggu

AU = Average unit atau pemakaian rata-rata selama waktutunggu

SS $\quad=$ Safety stock atau persediaan pengaman

5. Biaya total persediaan (Total Inventory Cost)

Dalam perhitungan biaya total persediaan, bertujuan untukmembuktikan bahwa dengan terdapatnya jumlah pembelianbahan baku yang optimal, yang dihitung dengan metode EOQakan dicapai biaya total persediaan baku yang minimal. TotalInventory Cost (TIC) dapat diformulasikan sebagai berikut:

$$
\mathrm{TIC}=\sqrt{2 \cdot D \cdot S \cdot h}
$$

Keterangan :

$\mathrm{D}=$ jumlah kebutuhan barang dalam unit

$\mathrm{S}$ = biaya pemesanan setiap kali pesan

$\mathrm{H}=$ biaya penyimpanan

\section{HASIL DAN PEMBAHASAN}

\section{Kegiatan Produksi Roti Nikki Echo}

Kegiatan produksi yang dilakukan di roti Nikki Echo dimulai dengan penyediaan bahan baku. Bahan baku yang digunakan sangat banyak, diantaranya: tepung terigu, gula pasir, mentega, bakerin plus, ragi instan, tepung susu, butter, coklat filling pasta, coklat filling bubuk, vanile bubuk, kalsium, keju, sponge, mentega putih, telur, wijen, minyak goring, mises, tepung ketan, pasta pandan, tepung maizena, dan kelapa parut.

Bahan baku yang digunakan diantar oleh pemasok yang sudah berlangganan dengan perusahaan. Pemasok yang mengantarkan dari daerah yang berbeda-beda. Pemasok akan datang apabila dihubungi oleh pihak perusahaan untuk menambah persediaan. Penambahan persediaan ini biasanya dilakukan 23 hari sebelum persediaan di gudang habis. Persediaan bahan baku di gudang masih belum dimanajemen dengan baik oleh pihak perusahaan. Tepung terigu yang digunakan dalam kegiatan produksi di roti Nikki Echo dipesan pada toko grosir “AJ Grosir" yang berada di daerah Piladang, Kabupaten Lima Puluh Kota 
dengan merek dagang "Terigu Gerbang”. Pemesanan yang dilakukan dengan menggunakan satuan karung dengan berat per karung sebesar $25 \mathrm{~kg}$. Adapun pembelian bahan baku tepung terigu pada tahun 2017 dapat dilihat pada Tabel1 di bawah ini

Tabel 1. Pembelian bahan baku

\begin{tabular}{|c|c|c|}
\hline No & Bulan & Jumlah Pembelian (Kg) \\
\hline 1 & Januari & 10,000 \\
\hline 2 & Februari & 7,450 \\
\hline 3 & Maret & 7,500 \\
\hline 4 & April & 10,000 \\
\hline 5 & Mei & 10,000 \\
\hline 6 & Juni & 10,000 \\
\hline 7 & Juli & 12,500 \\
\hline 8 & Agustus & 10,000 \\
\hline 9 & September & 8,750 \\
\hline 10 & Oktober & 10,000 \\
\hline 11 & November & 10,000 \\
\hline 12 & Desember & 10,000 \\
\hline \multicolumn{2}{|c|}{ Total } & 116.200 \\
\hline \multicolumn{2}{|c|}{ Rata-rata } & 9,683 \\
\hline
\end{tabular}

Jumlah pembelian bahan baku setiap bulan mengalami fluktuasi. Jumlah pembelian tertinggi pada bulan juli yang bertepatan dengan bulan ramadhan. Hal ini sesuai dengan yang diungkapkan pemilik bahwa produksi pada bulan ramadhan lebih tinggi dibandingkan hari-hari lainnya.

Kegiatan produksi dan pengemasan yang dilakukan perusahaan merupakan rangkaian kegiatan yang berlangsung setiap hari di roti Nikki Echo. Kegiatan produksi dilakukan mulai dari jam 6 pagi sampai selesai setiap harinya. Dalam kegiatan produksi yang dibuat adalah aneka jenis roti berupa; roti tawar, roti manis, roti isi kelapa, roti isi krim pandan, roti isi coklat, roti burger, dan selai roti. Rata-rata jumlah produksi dalam 1 hari 20-21 karung terigu atau setara dengan 500-525 kg terigu. Satu hari produksi akan menghasilkan 195 buah roti tawar, 62 buah roti kupas, 192 roti manis kecil, 108 roti manis besar, 6.396 roti isi kelapa, 1.848 roti burger, dan 432 roti sisir (Nikki Echo, 2018).

Pengemasan dilakukan setelah roti dingin yaitu sekitar 3-4 jam setelah proses pemanggangan. Pelaksanaan produksi roti dilakukan oleh tenaga kerja pria, hal ini dikarenakan pekerjaan dalam produksi yang cukup berat. Sedangkan pengemasan roti dilakukan oleh tenaga kerja wanita dengan alasan wanita lebih teliti dalam bekerja dibandingkan pria. Setelah pengemasan, langsung dilakukan kegiatan pemasaran.

Pemasaran yang dilakukan di roti Nikki Echo dilakukan ke berbagai tempat dengan berbagai cara. Wilayah pemasarannya meliputi Bukittinggi, Batusangkar, Lintau, Pasaman, Solok, Baso, Payakumbuh, Maninjau, dan Lima Puluh Kota. Pemasaran dilakukan dengan motor, mobil, dan penjualan langsung di pabrik. Saat ini pemasaran mulai dilakukan di media sosial.

\section{Manajemen Persediaan Tepung Terigu}

Manajemen yang diterapkan di roti Nikki Echo masih sangat sederhana. Dalam menjalankan usaha roti, perencanaan yang dilakukan oleh pihak perusahaan tidak dalam bentuk rencana yang tertulis, hal ini diungkapkan oleh pemilik usaha yang menyatakan "perencanaan dalam dokumen tertulis masih belum dilakukan oleh perusahaan, hanya saja pemilik bertujuan untuk meningkatkan produksi setiap harinya". Dalam pengadaan persediaan tepung terigu, perlu adanya biaya-biaya yang dikeluarkan oleh perusahaan. Biaya ini akan menambah biaya produksi yang harus dikeluarkan oleh perusahaan. Dengan adanya penambahan pada biaya produksi, maka manajemen persediaan pada bahan baku sangat penting digunakan oleh perusahaan untuk meminimalisir biaya produksi yang akan dikeluarkan.

\section{Biaya Pemesanan}

Biaya pesanan tepung terigu dalam kurun waktu satutahun dapat dilihat pada Tabel 2 di bawah ini. Pemesanan tepung terigu dalam 1 tahun yang dilakukan perusahaan memerlukan biaya sebesar Rp 4.895.200 per tahun. Sehingga untuk 1 kali pemesanan dikeluarkan biaya sebesar Rp 122.380. 
Tabel 2. Biaya pemesanan tepung terigu dalam 1 tahun

\begin{tabular}{llcr}
\hline & Jenis Biaya & \multicolumn{2}{c}{ Jumlah Biaya } \\
\hline 1 & Biaya telepon & $\mathrm{Rp}$ & 247.200 \\
2 & Biaya pengiriman & $\mathrm{Rp}$ & 4.648 .000 \\
\hline \multicolumn{2}{l}{ Total biaya pemesanan } & $\mathrm{Rp}$ & 4.895 .200 \\
\hline
\end{tabular}

\section{Biaya Penyimpanan}

Biaya penyimpanan tepung terigu pada roti Nikki Echo dalam 1 tahun dapat dillihat pada Tabel 3 di bawah ini

Tabel 3. Rincian biaya penyimpanan tepung terigu di roti Nikki Echo dalam 1 tahun

\begin{tabular}{|c|c|c|}
\hline No & Jenis Biaya & Jumlah Biaya \\
\hline 1 & Biaya gudang & $\mathrm{Rp} \quad 4.800 .000$ \\
\hline 2 & Biaya listrik & $\mathrm{Rp} \quad 120.000$ \\
\hline 3 & Biaya tenaga kerja & $\mathrm{Rp} \quad 6.000 .000$ \\
\hline Total & aya penyimpanan & Rp 10.920.000 \\
\hline
\end{tabular}

Biaya penyimpanan yang harus dikeluarkan perusahaan selama 1 tahun sebesar Rp 10.920.000. Dengan demikian biaya produksi juga akan bertambah sebesar biaya penyimpanan yang dikeluarkan. Biaya penyimpanan untuk $1 \mathrm{~kg}$ terigu dalam 1 tahun dapat dihitung sebagai berikut :

Biaya penyimpanan $/ \mathrm{kg} / \mathrm{tahun}=$ total biaya penyimpanan : total bahan baku

$$
\begin{aligned}
& =\operatorname{Rp} 10.920 .000: 116.200 \mathrm{~kg} \\
& =\operatorname{Rp} 94 / \mathrm{kg} / \text { tahun. }
\end{aligned}
$$

Sehingga diperoleh biaya penyimpanan per kg per tahun sebesar Rp 94

\section{Total biaya (TC) Berdasarkan Kebijakan Perusahaan}

Total biaya yang harus dikeluarkan perusahaan berdasarkan kebijakan yang diterapkan perusahaan adalah :

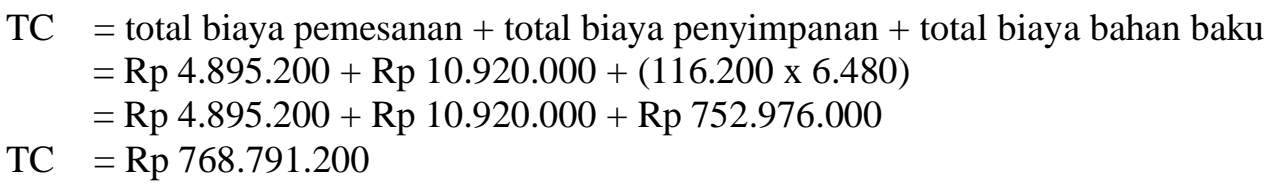

\section{Perhitungan Jumlah Pemesanan dengan EOQ}

Jumlah pemesanan yang ekonomis dapat dihitung dengan metode EOQ sebagai berikut :

$$
\begin{aligned}
\text { EOQ } & =\sqrt{\frac{2 D S}{H}} \\
& =\sqrt{\frac{2 \times 116.200 \times R p 122.380}{R p 94}} \\
& =17.394 \mathrm{Kg}
\end{aligned}
$$

Jumlah pemesanan yang ekonomis berdasarkan perhitungan dengan metode EOQ sebesar $17.394 \mathrm{~kg}$ per pesan atau setara dengan 696 karung dalam satu kali pemesanan. Jumlah pemesanan ini lebih besar dibandingkan jumlah rata-rata pembelian tepung terigu yaitu $9.683 \mathrm{~kg}$. Sehingga terjadi peningkatan jumlah pesan sebesar $7.711 \mathrm{~kg}$ atau setara dengan $79,6 \%$.

\section{Frekuensi Pembelian}

$$
\begin{aligned}
\text { I } & =\frac{D}{E O Q} \\
& =\frac{116.200}{17.394} \\
& =6,7 \text { kali } \\
\text { I } & =7 \text { kali pemesanan. }
\end{aligned}
$$


Jumlah frekuensi yang dilakukan oleh perusahaan apabila menggunakan metode EOQ sebanyak 7 kali. Jumlah ini memiliki selisih yang sangat besar dibandingkan frekuensi yang dilakukan oleh perusahaan yaitu 40 kali pemesanan.

\section{Persediaan Pengaman}

Penentuan jumlah safety stock bertujuan untuk mengetahui persediaan minimum yang dimiliki perusahaan untuk menghindari kemungkinan keterlambatan datangnya bahan baku. Besarnya safety stock dapat dihitung dengan :

Safety stock = (pemakaian maksimum-pemakaian rata-rata) $\mathrm{x}$ waktu tunggu

$$
\begin{aligned}
& =(12.500 \mathrm{~kg}-9.683 \mathrm{~kg}) \times 3 \text { hari } \\
& =2.817 \mathrm{~kg} \mathrm{x} 3 \\
& =8.451 \mathrm{~kg}
\end{aligned}
$$

Menghindari kurangnya persediaan sebelum bahan baku datang maka perusahaan harus memiliki persediaan pengaman sebesar $8.451 \mathrm{~kg}$.

\section{Titik Pemesanan Kembali}

Reorer point dihitung untuk menetukan kapan akan dilakukan pemesanan kembali. Reorer point dapat dihitung sebagai berikut :

$$
\begin{aligned}
\text { Reorder point } & =(\mathrm{LD} \times \mathrm{AU})+\mathrm{SS} \\
& =(3 \times 600)+8.451 \\
& =10.251 \mathrm{~kg}
\end{aligned}
$$

Pemesanan akan dilakukan ketika persediaan yang dimiliki perusahaan sebanyak $10.251 \mathrm{~kg}$.

\section{Biaya Total Persediaan dengan EOQ}

Penentuan biaya total persediaan dengan metode EOQ berguna untuk membandingkan apakah biaya yang dikeluarkan dengan kebijakan perusahaan berbeda dengan biaya yang ikeluarkan melalui perhitungan metode EOQ. Biaya total persediaan dihitung dengan cara berikut :

$$
\begin{aligned}
\text { TIC } & =\sqrt{2 . D . S . h} \\
& =\sqrt{2 \times 116.200 \times \operatorname{Rp~} 122.380 \times \mathrm{Rp} \mathrm{94}} \\
\text { TIC } & =\operatorname{Rp} 1.635 .073 \text { per pesan } \\
& =\operatorname{Rp} 11.445 .513 \text { per tahun }
\end{aligned}
$$

Perhitungan biaya total persediaan dengan metode EOQ adalah sebanyak Rp 11.445.513. Hal ini berarti biaya total persediaan yang didapatkan menggunakan metode EOQ lebih kecil dibandingkan biaya total yang dikeluarkan menggunakan kebijakan perusahaan.

\section{Perbandingan}

Perbandingan dari paramter-parameter dapat dilihat pada Tabel 4 di bawah ini

Tabel 4 perbandingan dari parameter

\begin{tabular}{clrr}
\hline No & Parameter Pembanding & Kebijakan Perusahaan & \multicolumn{1}{c}{ Metode EOQ } \\
\hline 1. & Pembelian rata-rata bahan baku & $9.683 \mathrm{~kg}$ & $17.394 \mathrm{~kg}$ \\
2. & TIC & Rp 768.791 .200 & Rp 11.445.513 \\
3. & Frekuensi pemesanan & $40 \mathrm{kali}$ & $7 \mathrm{kali}$ \\
4. & Safety stock & - & $8.451 \mathrm{~kg}$ \\
5. & Reorder point & - & $10.251 \mathrm{~kg}$ \\
\hline
\end{tabular}

\section{KESIMPULAN}

Penelitian ini dapat ditarik kesimpulan Jumlah persediaan yang ekonomis menggunakan metode EOQ pada perusahaan roti Nikki Echo sebesar $17.394 \mathrm{~kg}$, jumlah ini lebih besar dibandingkan rata-rata pemesanan yang dilakukan oleh perusahaan. Jumlah ini meningkat 79,6\% dari jumlah pemesanan sebelumnya. Besarnya reorder point menggunakan metode EOQ adalah $10.251 \mathrm{~kg}$ dengan waktu tunggu 
persediaan selama 3 hari. Total biaya persediaan bahan baku tepung terigu menggunakan metode EOQ sebesar Rp 11.445.513. Nilainya lebih kecil dibandingkan total biaya yang dikeluarkan perusahaan dengan kebijakan perusahaan. Penurunan biaya ini sebanyak $98 \%$ dari kebijakan perusahaan karena jumlah pemesanan yang berkurang $82,5 \%$ dari jumlah sebelumnya.

\section{DAFTAR PUSTAKA}

Kusuma, H. 2009. Manajemen Produksi. Penerbit Andi : Yogyakarta.

Slamet, Achmad. 2007. Penganggaran Perencanaan dan Pengendalian Usaha. Semarang : UNNES PRESS.

Handoko, T. Hani. 2000. Dasar-dasar Manajemen Produksi dan Operasi. Yogyakarta : BPFE.

Zulfikarijah. 2005. Manajemen Persediaan. Universitas Muhammadiyah. Malang. 